KRZYSZTOF A. MAKOWSKI

https://orcid.org/0000-0003-4674-530X

Uniwersytet im. Adama Mickiewicza w Poznaniu

\title{
ŻYDZI W KRAKOWSKIM SAMORZĄDZIE. O KSIĄŻCE HANNY KOZIŃSKIEJ-WITT POLITYCY CZY KLAKIERZY? ŻYDZI W KRAKOWSKIEJ RADZIE MIEJSKIEJ W XIX WIEKU, WYDAWNICTWO UNIWERSYTETU JAGIELLOŃSKIEGO, KRAKÓW 2019 (STUDIA NAD CYWILIZACJĄ ŻYDOWSKA W POLSCE, 3), SS. 245 + 3, FAKSYMILIA, FOTOGRAFIE, ILUSTRACJE
}

Zarys treści: Niniejszy artykuł zawiera refleksje na temat książki Hanny Kozińskiej-Witt pt. Politycy czy klakierzy? Żydzi w krakowskiej radzie miejskiej w XIX wieku (Kraków 2019). Autorka za cel postawiła sobie weryfikację tezy, że aktywność żydowskich radnych była nieadekwatna do ich liczby. Posłużyła się teoria aren Dietlind Hüchtker. Książka składa się z wprowadzenia, czterech rozdziałów i ekskursu. W warstwie informacyjnej należy ja uznać za wartościowa. W zestawieniu z wcześniejszymi publikacjami na temat udziału Żydów w krakowskiej radzie miejskiej porusza szersza gamę problemów i przynosi wiele nowych ustaleń. Gorzej wypada warstwa konstrukcyjna i ogólnie warsztatowa.

The content outline: The article present reflections on the book Politycy czy klakierzy? Żydzi w krakowskiej radzie miejskiej w XIX wieku (Kraków, 2019) by Hanna Kozińska-Witt. The author of the publication sought to verify the thesis according to which the activity of Jewish councillors in Kraków was not proportionate to their number. For this purpose, she used the theory of arenas developed by Dietlind Hüchtker. The book consist of introduction, four chapters, and an excursus. Hanna Kozińska-Witt's book is a valuable source of information. In comparison to earlier publications on the participation of Jews in Kraków's municipal council, it tackles a broader set of issues and offers fresh research outcomes. However, the construction and overall methodological aspect of the book is lacking.

Słowa kluczowe: Żydzi, Kraków, rada miejska, XIX w.

Keywords: Jews, Kraków, municipal council, nineteenth century 
Hanna Kozińska-Witt, autorka recenzowanej książki, wcześniej związana m.in. z Geisteswissenschaftliches Zentrum für Geschichte und Kultur Ostmitteleuropas i Simon-Dubnow-Institut w Lipsku, a w ostatnich latach z Instytutem Judaistyki Uniwersytetu Jagiellońskiego w Krakowie (obecnie przedstawia się jako freelancerka), ma ugruntowana pozycję na polu studiów żydowskich. Od kilkunastu przynajmniej lat szczególne miejsce w jej badaniach zajmuje aktywność Żydów w samorządzie miejskim na ziemiach polskich w XIX i XX w. W tym nurcie mieści się również omawiana książka. Dotyczy ona bowiem - ogólnie rzecz biorąc aktywności Żydów w krakowskiej radzie miejskiej w XIX w. Autorka za cel postawiła sobie weryfikację lansowanej w literaturze tezy, że była ona niewielka, a w każdym razie nieadekwatna do liczby żydowskich radnych. Postanowiła wykazać, że było inaczej. W swych badaniach posłużyła się zaproponowaną przez niemiecką historyczkę Dietlind Hüchtker w książce Geschichte als Performance. Politische Bewegungen in Galizien um 1900 (Frankfurt am Main 2014) teoria aren, rozumianych jako konkretne płaszczyzny działalności politycznej, na których, według jasno określonych zasad, „podnoszono z góry określone tematy”.

Wprawdzie problematyka udziału Żydów w krakowskiej radzie miejskiej w XIX stuleciu była już przedmiotem zainteresowania historyków (w ostatnich latach głównie Łukasza Tomasza Sroki ${ }^{1}$ ), ale autorka recenzowanej książki przedstawiła nieco szersze ujęcie problemu, podejmując pewne wątki, które nie były dotąd poruszane. W tym miejscu należy dodać, że zawartość merytoryczna pracy jest dużo większa, niż sugerowałby to jej tytuł. I ta jego nieadekwatność względem treści książki budzi moje zastrzeżenia. Do tego problemu będę jeszcze wracał w dalszych częściach recenzji. Tu natomiast chciałbym zwrócić uwagę, że tytuł pracy budzi także wątpliwości innej natury, powiedziałbym semantycznej (zjawisko dziś, niestety, dość częste). Przede wszystkim mam na myśli użyte przez autorkę w jego głównej (literackiej) części pojęcia. O ile na nazwanie samorządowców „politykami” można przymknąć oko (wszak dziś wszystko jest polityka), o tyle słowo „klakierzy" w ogóle nie pasuje do kontekstu. Pojęcie to - według słownikowej definicji - oznacza bowiem ludzi wynajętych do oklaskiwania aktorów lub widowiska, a w języku potocznym ludzi, którzy gorliwie komuś

${ }^{1}$ Z nowszych prac należy wskazać Ł.T. Sroka, Żydzi $w$ Krakowie. Studium o elicie miasta 1850-1918, Kraków 2008 (gdzie m.in. dwudziestostronicowy rozdział pt. W samorzqdzie miejskim) czy towarzyszący wystawie (o tej samej nazwie) zbiór studiów zatytułowany Budowali nowoczesny Kraków. Żydzi w samorzadzie miejskim, gospodarczym i finansowym miasta (1866-1939), red. B. Cisowska, Kraków 2015. 
przytakuja. Autorce zaś - jak wynika ze wstępu - chodziło o zbadanie, czy Żydzi w krakowskiej radzie miejskiej odgrywali aktywną rolę, czy też byli raczej biernymi obserwatorami wydarzeń. Chcąc obrazowo oddać pasywną postawę, zamiast słowa „klakierzy” należałoby przeto raczej użyć - zaczerpniętego również z języka teatralnego - pojęcia „statyści”. Na dodatek, opatrując ów tytuł znakiem zapytania, autorka chyba przyjęła, że oba terminy (,politycy” i „klakierzy/statyści”) wykluczaja się nawzajem. Tymczasem takiej zależności między nimi absolutnie nie ma. Polityk (też samorządowiec) może bowiem być (i najczęściej był/jest) jednocześnie także klakierem/statystą i vice versa. Poruszając wątek semantyczny, pragnę podzielić się jeszcze jedną uwaga. Otóż wydaje mi się, że niezbyt szczęśliwe jest używanie w książce przez autorkę zaczerpniętego ze źródeł pojęcia „radca”, ponieważ dziś termin ten ma całkiem inne znaczenie. Bardziej komunikatywna byłaby - moim zdaniem - uwspółcześniona wersja „radny”.

Hanna Kozińska-Witt z pewną dowolnościa potraktowała także ramy chronologiczne książi. W podtytule znajdujemy bowiem zapowiedź, że rozważania będę dotyczyły XIX w. I choć w narracji zdarzaja się elementy retrospekcji, to autorka, co zreszta expressis verbis stwierdza we wprowadzeniu, zasadniczo zajmuje się okresem między wydaniem dwóch statutów gminnych dla Krakowa - z 1866 (tymczasowego) i 1901 r. Jako że w pewnych partiach rozprawy narracja została doprowadzona do 1914 r., należało raczej po prostu napisać, że dotyczy ona okresu autonomicznego.

Recenzowana książka składa się z krótkiego wprowadzenia, czterech dość proporcjonalnych rozdziałów (wszystkie liczą po ok. 40 stron) oraz ekskursu. Poszczególne części podzieliła autorka na bardzo liczne i stosunkowo krótkie podrozdziały, co, moim zdaniem, nie nadało bynajmniej pracy spójności. Rozdział pierwszy ma charakter wprowadzający. Autorka kreśli w nim sytuację prawną Żydów i gmin żydowskich w Galicji. Koncentruje się na genezie i treści statutu dla krakowskiego „zboru izraelickiego” z 1870 r. oraz późniejszych jego modyfikacjach, zwłaszcza na ustawie z $1890 \mathrm{r}$. Na tym tle dość szeroko przedstawia również sylwetki dwóch ważnych w tamtym czasie dla życia politycznego Krakowa i Galicji postaci - czołowego antysemity Teofila Merunowicza i ortodoksyjnego rabina krakowskiego Szymona Szreibera - i ich poglądy na temat kwestii wyznaniowych.

Kolejny rozdział, bez watpienia kluczowy dla całej pracy, nieco zaskakuje - zarówno ze względu na swój tytuł, jak i zawartość merytoryczna. Autorka zatytułowała go bowiem $\dot{Z} y d z i$ w krakowskiej radzie miejskiej, co zasadniczo brzmi tak samo, jak tytuł całej książki. Hanna 
Kozińska-Witt zajmuje się tu pozycją Żydów w krakowskim samorządzie, szukając przede wszystkim odpowiedzi na pytanie, czy byli oni jak sugerowano dotychczas - aż tak zależni od swych nieżydowskich kolegów. Podejmuje tu zatem kwestię kluczową dla całej książki. W tym momencie zacząłem się wszakże zastanawiać, co w takiej sytuacji będzie przedmiotem rozważań w dalszej jej części, ale o tym oczywiście dalej. W omawianym rozdziale Autorka przedstawia krakowskie statuty z 1866 i 1901 r., a dalej wybory do rady miejskiej, które - jej zdaniem dopiero od lat osiemdziesiątych nabrały temperatury, oraz strukture społeczną i wyznaniową radnych (co istotne, liczba Żydów wzrastała). Przy tej okazji pozwolę sobie na drobną polemikę. Pisząc o pochodzeniu żydowskich radnych z poszczególnych kurii, Autorka stwierdziła bowiem, że z kurii II (,posiedzicieli”) Żydzi zasadniczo się nie rekrutowali, ponieważ współtworząca ją wraz z właścicielami ziemskimi, grupa kamieniczników była zdominowana przez chrześcijan. Tymczasem, jak wynika m.in. z badań Kazimierza Karolczaka, odsetek „posiedzicieli” domów wyznania mojżeszowego był w Krakowie relatywnie wysoki² Inna musiała więc być przyczyna, dla której zasiadający w radzie Żydzi reprezentowali głównie kurię III (handel).

W dalszej części tegoż rozdziału Autorka przedstawia działalność żydowskich radnych, zwłaszcza ich aktywny udział w sekcjach i komisjach. Słusznie podkreśla, że samorząd był wtedy jedna z nielicznych płaszczyzn, na których krzyżowały się drogi Żydów i reprezentantów „świata zewnętrznego”. Jednocześnie było to też główne forum, na którym podnoszono publicznie sprawy żydowskie. Wywody Autorki na ten temat skłaniają do szerszych refleksji. Zwraca ona uwagę, że w literaturze żydowskim radnym przypisywano nie tylko wysoki poziom kompetencji, ale wręcz swoiste poczucie misji. Postrzega to jako element rodzącej się w XIX w. postawy obywatelskiej. Wprawdzie nie do końca rozumiem, co się za tym hasłem kryje, ale wydaje mi się, że decydujące znaczenie miał $\mathrm{w}$ tym wypadku raczej lansowany przez pozytywistów etos inteligencki, który stał się wtedy atrakcyjny również dla wielu maskilów. A jednym z ważniejszych jego elementów była wszak „służba społeczna”. Hanna Kozińska-Witt zauważa, że żydowscy radni głównie podnosili sprawy swoich współwyznawców, przede wszystkim w zakresie oświaty. Dążyli - jej zdaniem - do tego, aby „papierowe równouprawnienie stało się rzeczywistością" (s. 84). Nie zauważa wszakże,

${ }^{2}$ K. Karolczak, Ludność żydowska $w$ Krakowie na przełomie XIX i XX wieku, w: Żydzi w Małopolsce. Studia z dziejów osadnictwa i życia społecznego, red. F. Kiryk, Przemyśl 1991, s. 253-254. 
że tu właśnie uwidacznia się owe błędne koło czy pułapka, w która powszechnie wpadali zwolennicy integracji. W założeniach chcieli oni bowiem zabiegać o ogólny postęp ludzkości (a tylko przy okazji także i o awans społeczny Żydów), a w rzeczywistości ciągle musieli walczyć o partykularne cele. Przez chrześcijan, nie tylko na ziemiach polskich, było to wszelako postrzegane jako pozorna integracja i podwójna lojalność. W konsekwencji prowadziło to do klęski haskali, bo oczekiwana przez asymilacjonistów absorbcja Żydów przez społeczeństwo większościowe nie następowała. $\mathrm{Z}$ cała moca uwidoczniło się to $\mathrm{w}$ okresie międzywojennym. Autorka podkreśla, że po retorykę antyżydowską sięgano jednak na forum krakowskiej rady stosunkowo rzadko. Na końcu tej części znalazły się: załącznik z alfabetyczną listą żydowskich radnych z okresu 1866-1914 i wkładka z ich podziałem według kadencji (za lata 1896-1914).

Kolejne dwa rozdziały zdaja się być wykreowane nieco sztucznie. Zasadniczo też dotyczą bowiem aktywności Żydów na forum rady, czyli problematyki poruszanej już w poprzedniej części. Niestety, Autorka nie wyjaśnia, dlaczego akurat te dwa wątki zasłużyły na wyodrębnienie. I tak, w rozdziale trzecim Hanna Kozińska-Witt, przez pryzmat subwencji przyznawanych żydowskim instytucjom charytatywnym, analizuje skuteczność żydowskiego „lobbingu” w krakowskiej radzie. Zwraca uwagę, że mimo rosnacej roli samorządu i państwa w dziedzinie dobroczynności w Krakowie do końca doby autonomicznej wsparcia udzielano poprzez instytucje konfesyjne. Wydaje mi się, że szczególnie ważne byłoby tu ukazanie, w jakim stopniu Żydzi wpływali na ostateczny proces decyzyjny. A tego akurat wątku Autorka nie podjęła.

W ostatnim rozdziale Hanna Kozińska-Witt starała się z kolei ukazać, jaką rolę odegrał krakowski samorząd, a zwłaszcza żydowscy radni, w programie modernizacji Kazimierza, czyli procesie integracji dzielnicy żydowskiej z chrześcijańskim Śródmieściem, choć o ważnej roli Żydów, zwłaszcza w stymulowaniu rozwoju szkolnictwa, pisze zasadniczo dopiero w podsumowaniu tej części. Zaznacza, że mimo wysiłków Kazimierz pozostał mniej rozwinięty. Samorząd w gruncie rzeczy konserwował bowiem konfesyjne podziały, dopuszczając do Śródmieścia jedynie majętnych i wykształconych Żydów. Autorka zastanawia się, czy nie była to „selektywna integracja pożądanych jednostek” (s. 180). Moim zdaniem nie było w tym wszakże nic wyjątkowego. Wręcz przeciwnie, koncentracja elity w centrach większych miast była w XIX w. zjawiskiem dość typowym, przede wszystkim dlatego, że ludzi z niższych warstw społecznych nie było po prostu stać na zamieszkiwanie w śródmiejskich dzielnicach. 
Jeszcze luźniej z tematyką książki związany jest wieńczący ją całkiem obszerny (liczacy ponad 30 stron) ekskurs poświęcony ciagnącym się od 1882 do 1886 r. procesom pochodzacego z Lutczy koło Rzeszowa małżeństwa Gitli i Mojżesza Ritterów, których oskarżono o mord rytualny. Owe procesy, z których dwa toczyły się w Krakowie (i jakich wiele toczyło się w różnych częściach ówczesnej Europy), ostatecznie zakończyły się uniewinnieniem. Autorka opisuje je barwnie i dość szczegółowo. Uważa, że dla krakowskiej opinii publicznej relacje z procesów miały przede wszystkim wymiar sensacyjny i rozrywkowy. Ponadto uwidoczniły narodziny medialnej „czwartej władzy”. Zdaniem Hanny Kozińskiej-Witt sprawa Ritterów przyczyniła się także do „okrzepnięcia” galicyjskiego antysemityzmu. W tym poszlakowym procesie mieszkańcy Krakowa mieli bowiem a priori uznać winę Ritterów, którzy według Autorki - stali się ucieleśnieniem wszystkich Żydów. Nie jestem przekonany, czy takie uogólnienie jest tu uprawnione. Jeśli jednak tak było, to nie wystawiałoby to dobrego świadectwa przede wszystkim ówczesnym krakowskim elitom. W sumie omawiany ekskurs stanowi zamkniętą całość, dość odległą od meritum rozważań. Zresztą niedawno ukazał się po angielsku jako osobny artykuł ${ }^{3}$.

Na końcu książki pomieściła autorka streszczenie w języku angielskim i hebrajskim, spisy ilustracji i tabel oraz bibliografię.

Praca oparta została na różnorodnym materiale źródłowym. W pierwszej kolejności Autorka sięgnęła po różnego rodzaju źródła drukowane, zwłaszcza publikacje wydawane przez samorząd oraz prasę (w sumie 12 tytułów, głównie „Reforma” i „Nowa Reforma”). Wykorzystała także archiwalia, przede wszystkim protokóły z posiedzeń rady miejskiej i akta magistrackie z zasobu Archiwum Narodowego w Krakowie oraz akta krakowskiej gminy żydowskiej ze zbiorów Żydowskiego Instytutu Historycznego w Warszawie. Autorka dość obficie sięgnęła też po literaturę przedmiotu. Aczkolwiek widoczne są pewne luki. Można tu wymienić choćby pominięte przez nią starsze publikacje o szkolnictwie elementarnym w Galicji, np. broszurę Teofila Fiutowskiego ${ }^{4}$ czy książkę Waldemara Łazugi o rządach Kazimierza hr. Badeniego ${ }^{5}$, gdzie m.in. pojawia się wątek tzw. Wiener Frage, który pozwoliłby być może ukazać szerszy kontekst omawianych w recenzowanej pracy zagadnień.

${ }^{3}$ H. Kozińska-Witt, Unwarranted Notoriety? The Ritter Trials, 1882-1886, „Studia Judaica" 23, 2020, nr 1, s. 75-109.

${ }_{4}^{4}$ T. Fiutowski, Szkolnictwo ludowe w Galicyi w dobie porozbiorowej, Lwów 1913.

${ }^{5}$ W. Łazuga, „Rzady polskie” w Austrii. Gabinet Kazimierza hr. Badeniego 1895-1897, Poznań 1991. 
Podsumowując, pragnę stwierdzić, że w warstwie informacyjnej książkę Hanny Kozińska-Witt należy uznać za wartościowa. W zestawieniu z wcześniejszymi publikacjami na temat udziału Żydów w krakowskiej radzie miejskiej porusza ona bowiem szerszą gamę problemów i przynosi wiele nowych ustaleń. Gorzej wypada warstwa konstrukcyjna i ogólnie warsztatowa. Książka jest bowiem w istocie zbiorem dość luźno ze soba powiazanych studiów dotyczących aktywności żydowskiej elity Krakowa w dobie autonomicznej, z wiodącym motywem jej działalności na forum rady miejskiej. W związu z tym praca powinna-moim zdaniem - nosić inny tytuł, bardziej adekwatny do jej treści. I - jak starałem się wykazać - nie chodzi tu bynajmniej tylko o owych „klakierów”. W konsekwencji inaczej powinny brzmieć też tytuły przynajmniej niektórych rozdziałów, inaczej mogłaby też wyglądać ich struktura wewnętrzna. Odnosi się to zwłaszcza do owych licznych krótkich podrozdziałów, czasem dobranych jakby przypadkowo, co wywołuje wrażenie intelektualnego chaosu.

\section{Bibliografia}

Budowali nowoczesny Kraków. Żydzi w samorzadzie miejskim, gospodarczym i finansowym miasta (1866-1939), red. B. Cisowska, Kraków 2015.

Fiutowski T., Szkolnictwo ludowe w Galicyi $w$ dobie porozbiorowej, Lwów 1913.

Karolczak K., Ludność zydowska w Krakowie na przełomie XIX $i$ XX wieku, w: Żydzi w Małopolsce. Studia $z$ dziejów osadnictwa $i$ życia społecznego, red. F. Kiryk, Przemyśl 1991, s. 251-264.

Kozińska-Witt H., Die Krakauer Jüdische Reformgemeinde 1864-1874, Frankfurt am Main 1999.

Kozińska-Witt H., Krakauer Munizipalität und jüdische Konfessionsgemeinde. „Provisorisches Gemeindestatut für die königliche Hauptstadt Krakau“ (1866) und seine Wirkung, „Historica. Revue pro historii a přibuzeně vědy” 1, 2015, s. 58-68.

Kozińska-Witt H., Unwarranted Notoriety? The Ritter Trials, 1882-1886, „Studia Judaica" 23, 2020, nr 1, s. 75-109.

Łazuga W., „Rzqdy polskie” w Austrii. Gabinet Kazimierza hr. Badeniego 1895-1897, Poznań 1991.

Sroka Ł.T., Żydzi w Krakowie. Studium o elicie miasta 1850-1918, Kraków 2008. 
Krzysztof A. Makowski

Jews in Kraków's self-government. On Hanna Kozińska-Witt's Politycy czy klakierzy? Żydzi w krakowskiej radzie miejskiej $w$ XIX wieku, Kraków, 2019 Summary

The book by Hanna Kozińska-Witt discusses the activity of Jews in Kraków's municipal council in the nineteenth century. The goal of the author is to verify the thesis according to which the activity of Jewish councillors was not proportionate to their number. For this purpose, she uses the theory of arenas developed by Dietlind Hüchtker. The book consist of introduction, four main chapters, and an excursus. The first chapter focuses on the legal status of Jews and Jewish communities in Galicia. The second chapter, of key importance to the entire book, is titled $\dot{Z} y d z i$ w krakowskiej radzie miejskiej (Jews in Kraków's Municipal Council). It deals with Kraków's statutes of 1866 and 1901, elections to the municipal council, and the social and religious structure of the councillors. It then goes on to discuss the activity of Jewish councillors, especially their keen involvement in the works of various sections and committees. The two subsequent chapters are also pertinent to the issue discussed in the preceding sections. The third chapter probes the effectiveness of Jewish "lobbying" in the municipal council, while the last chapter is an attempt to present the role of Kraków's self-government, especially its councillors, in the modernisation programme in the district of Kazimierz. The excursus is tangentially connected to the main focus of the book and concerns the legal troubles of the Ritter couple from Lutcza near Rzeszów, who were put before court on the charge of ritual murder and stood a series of trials in the years 1882-1886. The discussion is based primarily on printed sources and press. The book by Hanna Kozińska-Witt is a valuable source of information. In comparison to earlier publications on the participation of Jews in Kraków's municipal council, it tackles a broader set of issues and offers fresh research outcomes. However, the construction and overall methodological aspect of the book is lacking.

Krzysztof A. Makowski - profesor zwyczajny na Wydziale Historii Uniwersytetu im. Adama Mickiewicza w Poznaniu; kieruje Zakładem Historii XIX w. Zainteresowania badawcze ogniskują się wokół dziejów ziem polskich w XIX i XX w., przede wszystkim wokół dziejów rodziny, mobilności społecznej i procesów migracyjnych, a także dziejów ludności niemieckiej i żydowskiej oraz stosunków polsko-niemiecko-żydowskich, tożsamości, świadomości i pamięci historycznej oraz dziejów historiografii. Wiceprezydent Międzynarodowego Komitetu Nauk Historycznych, członek Komitetu Nauk Historycznych PAN, członek założyciel Polskiego Towarzystwa Studiów Żydowskich, a ponadto członek Commission Internationale des Études Historiques Slaves, International 
Commission on Historical Demography i Polskiego Towarzystwa Historycznego. Był m.in. stypendystą Fundacji Alexandra von Humboldta i Simon-Dubnow-Institut für jüdische Geschichte und Kultur w Lipsku. Wykładał w The University of Western Ontario w London (Kanada) i The University of Reading w Wielkiej Brytanii. Główne publikacje: Rodzina poznańska w I połowie XIX wieku, Poznań 1992 (wyd. niem. Die Posener Familie 1815-1848, Lüneburg 1996); Siła mitu. Żydzi w Poznańskiem w dobie zaborów w piśmiennictwie historycznym, Poznań 2004; Mechanizmy zamorskich migracji tańcuchowych w XIX wieku: Polacy, Niemcy, Żydzi, Rusini. Zarys problemu, Kraków 2004 (wraz z D. Praszałowicz i A.A. Zięba); jako redaktor: Samomodernizacja społeczeństw w XIX wieku: Irlandczycy, Czesi, Polacy, Poznań 1999 (wraz z L. Trzeciakowskim); O nowy model historycznych badań regionalnych, Poznań 2007; Approaches to Slavic Unity: Austro-Slavism, Pan-Slavism, Neo-Slavism, and Solidarity Among the Slavs Today, Poznań 2013 (wraz z F. Hadlerem); Dzieje kobiet w Polsce. Dyskusja wokót przyszłej syntezy, Poznań 2014.

Krzysztof A. Makowski - full professor at the Faculty of History of the Adam Mickiewicz University in Poznan, head of the Department of Nineteenth-Century History. His research interests focus on the history of Polish lands in the nineteenth and the twentieth century, primarily issues surrounding family, social mobility, and migratory processes, as well as the history of German and Jewish population and Polish-German-Jewish relations, identities, historical awareness and memory, and the history of historiography. Vice-president of the International Committee of Historical Sciences, member of the Committee of Historical Sciences of the Polish Academy of Sciences, founding member of the Polish Association for Jewish Studies, and member of the Commission Internationale des Études Historiques Slaves, International Commission on Historical Demography, and Polish Historical Society. He has been, among others, a fellow of the Alexander von Humboldt Foundation and the Simon-Dubnow-Institut für jüdische Geschichte und Kultur in Lepzig. He has lectured at the University of Western Ontario in London, Canada, and the University of Reading in Great Britain. His most important publications include: Rodzina poznańska $w$ I połowie XIX wieku, Poznań, 1992 (German edition: Die Posener Familie 1815-1848, Lüneburg, 1996); Siła mitu. Żydzi w Poznańskiem w dobie zaborów w piśmiennictwie historycznym, Poznań, 2004; Mechanizmy zamorskich migracji tańcuchowych w XIX wieku: Polacy, Niemcy, Żydzi, Rusini. Zarys problemu, Kraków, 2004 (co-authored with D. Praszałowicz and A.A. Zięba); as an editor: Samomodernizacja spoteczeństw $w$ XIX wieku: Irlandczycy, Czesi, Polacy, Poznań, 1999 (co-authored with L. Trzeciakowski); O nowy model historycznych badań regionalnych, Poznań, 2007; Approaches to Slavic Unity: Austro-Slavism, Pan-Slavism, Neo-Slavism, and Solidarity Among the Slavs Today, Poznań, 2013 (co-authored with F. Hadler); Dzieje kobiet w Polsce. Dyskusja wokót przyszłej syntezy, Poznań, 2014.

E-mail:makmak@amu.edu.pl 